\title{
Seismic Analysis of Floating Stone Columns in Soft Clayey Soil
}

\author{
Mahdi O. Karkush ${ }^{1, \text { a }}$, Amer G. Jihad ${ }^{2,}$, Karrar A. Jawad ${ }^{1, c^{*}}$, Mustafa S. Ali ${ }^{1, \text { d }}$, and \\ Bilal J. Noman ${ }^{1, \mathrm{e}}$ \\ ${ }^{1}$ Department of Civil Engineering, University of Baghdad, Baghdad, Iraq \\ ${ }^{2}$ Department of Road and Transport Engineering, University of Al-Qadisiyah, Al Diwaniyah, Iraq \\ amahdi_karkush@coeng.uobaghdad.edu.iq, bamer.ghani@qu.edu.iq \\ ckarrar.jawad2001d@coeng.uobaghdad.edu.iq, ${ }^{\mathrm{d}}$ mustafa.ali2001d@coeng.uobaghdad.edu.iq, \\ ebilal.noman2001d@coeng.uobaghdad.edu.iq
}

\begin{abstract}
The response of floating stone columns of different lengths to diameter ratio (L/D $=0,2$, $4,6,8$, and 10) ratios exposed to earthquake excitations is well modeled in this paper. Such stone column behavior is essential in the case of lateral displacement under an earthquake through the soft clay soil. ABAQUS software was used to simulate the behavior of stone columns in soft clayey soil using an axisymmetric finite element model. The behavior of stone column material has been modeled with a Drucker-Prager model. The soft soil material was modeled by the Mohr-Coulomb failure criterion assuming an elastic-perfectly plastic behavior. The floating stone columns were subjected to the El Centro earthquake, which had a magnitude of 7.1 and a peak ground acceleration of 3.50 $\mathrm{m} / \mathrm{s}^{2}$. The surface displacement, velocity, and acceleration in soft clayey enhanced by floating stone columns are also smaller than in natural soft clay. The findings of this research revealed that under the influence of earthquake waves, lateral displacement varies with stone columns of various lengths.
\end{abstract}

Keywords: Seismic analysis; floating stone column; soft soil; lateral displacement; earthquake; ABAQUS software.

\section{Introduction}

The majority of the soils in Iraq's middle and southern regions are soft to very soft cohesive soils, particularly in areas near marshes. In these areas, several projects are planned to be built. It is anticipated that over $1400 \mathrm{~km}$ of new railway networks will be created and the rehabilitation of the existing network [1]. The stone columns method is one of the soil improvement methods that is used to improve soft soils by increasing soil strength, decreasing soil compressibility, speeding up the consolidation rate, and lowering the liquefaction potential [2]. Dynamic loads on foundations and soil structures are caused by earthquakes, bomb explosions, and the operation of reciprocating and rotary machinery. The nature of each of these loads differs significantly from that of other loading scenarios. Because soft soils cannot be compacted, stone columns are commonly used. Because the stone columns are highly permeable, they act as vertical drains, allowing the soft clay around them to consolidate and improve the foundation's long-term performance.

However, only a few researchers investigated the efficacy of stone column methods in preventing permanent seismic deformation. The literature on seismic behavior and the performance of foundation systems with piles is extensive, but it has gotten little attention as a seismic countermeasure. Reference has recently looked into the idea of using stone columns to improve the rocking foundation concert [3]. Kim et al. [4] looked at the amplification of acceleration, shear strain, and shear wave velocity to compare the seismic response of unimproved and improved ground deposits. The stone column was shown to be capable of preventing large shear deformation in soil deposits. The acceleration of enhanced ground deposits may be amplified more than that of unimproved ground deposits when subjected to a short periodic seismic wave. Ryu and Kim [5] used a traditional approach to estimate the bearing capacity and settlement problem of soft clayey deposits improved by a single stone column and subjected to dynamic loading.

Vibroflotation equipment was used to perform a series of large-scale field experiments on stone columns. It has been confirmed that the shear strength parameters of the soil enhanced by stone columns are significantly greater than the parameters of the in-situ soils that existed before the stone 
column installation and that the resulting shear strength can safely resist horizontal forces caused by a $0.25 \mathrm{~g}$ ground acceleration [6]. The seismic damage in weak soil deposits can be minimized by implementing different ground improvement techniques like stone columns, soil-mix columns, deep soil mixing. The stone column method improves the seismic performance of liquefiable soil deposits in the following ways: reduces compressibility of soil deposits, increases shear strength of soil, dissipates excess pore water pressure, accelerates the consolidation settlement, and also reduces the dilatation property of the soil deposits [7]. Many researchers have studied the seismic response of improved and unimproved ground using shaking table tests [8,9]. In general, the finite element approach with software analysis plays an essential role in studying many geotechnical structures. It can show how dynamic loading affects these structures and highlight critical aspects of engineering practice [10]. Description of the total modeling by FEM method, including soil-structure interaction effect, is unified in the computer program ABAQUS [11]. This paper aims to investigate the response of floating stone columns under the influence of seismic loading. ABAQUS finite element program has been used for axisymmetric simulations, including the stone column and experimented soil conditions. Seismic numerical modeling of a single stone column of $0.03 \mathrm{~m}$ diameter with different $\mathrm{L} / \mathrm{D}$ ratios has been studied. This model was investigated by reference [12] as a single stone column in soft clay soil and subjected to the El Centro earthquake's ground acceleration.

\section{Soil Improvement by Stone Columns}

One of the most common ground improvement methods for treating soft soils is the use of stone columns. They act as reinforcement components, increasing bearing capacity and reducing settlement. Active seismic areas also decrease the liquefaction potential. They also accelerate the consolidation of the soil as an effect of the drainage capacity of the granular materials of the columns, which work as pore or water pressure evacuation points [13]. Using a 1g shaking test, Son et al. [14] investigated the dynamic behavior of a stone column foundation in clayey soil. Three input ground waves' reaction spectra and accelerations were examined concerning their distance from the foundation. The findings support the hypothesis that the acceleration was dampened from the outside. The acceleration of the foundation was observed to be dampened from the outside rather than the inside. Increasing the stiffness of the soil improved by crushed stone column caused shifting the natural ground period to the short-period region.

As a result, the acceleration outside the foundation was less than that within the foundation. When long-period seismic waves were applied, the crushed stone distance had no discernible effect on ground acceleration. However, the crushed stone's distance significantly influences the ground acceleration when applied short-period seismic waves. The installation of crushed stone in the ground led to a change in the ground stiffness, which led to a change in the period, as do the response spectra and the acceleration values. Wriggers [15] studied the behavior of granular columns that are set on a sloping layered deposit soil under seismic motions excitation, where the stone column and soil were modeled using 3D Opensees PL finite element software. When the peak ground acceleration, excess pore pressure, lateral displacement, and shear strain value were decreased by $0.7,2,6$, and $8 \%$, respectively, when a single column reinforced the soil, the difference in displacement, shear strain, excess pore pressure, and acceleration at different locations was analyzed.

\section{Seismic Loading}

Seismic loading, which is known as an application of seismic oscillation to a structure, can be considered one of the essential basics of earthquake engineering. It depends on seismic hazard, geotechnical site parameters, structural natural frequency, which occurs at the surface of the structure, which is in contact with the ground or an adjacent structure. For the years 2017 and 2018, seismic activities were recorded with different strengths in Iraq. During the last two months of the year 2017, more than seventy earthquakes hit Iraq. As shown in Table 1, the magnitude of these earthquakes ranged from 4.0 to 7.3 on the Richter scale, with depths ranging from 6.21 to $42.32 \mathrm{~km}$. 
Table 1. History of some earthquakes in Iraq.

\begin{tabular}{|c|c|c|}
\hline Year & $\begin{array}{c}\text { Magnitude (Richter } \\
\text { scale) }\end{array}$ & Location \\
\hline 1960 & 6.0 to 6.7 & Halabjah city which locates at the northeast of Baghdad \\
\hline 1967 & 6.1 & 100 km about south of Halabjah city, Iraq \\
\hline 2013 & 5.6 and 5.8 & Two Earthquakes hit about 60 km south of Halabjah city, Iraq \\
\hline 2017 & 7.3 & Series of earthquakes 30 km south of Halabjah city, Iraq \\
\hline 2018 & 4.0 to 4.5 & Series of earthquakes hit northeast of Baghdad, Iraq \\
\hline
\end{tabular}

\section{Numerical Modeling}

A single stone column was nominated from an experimental study on floating stone column behavior under different types of loading that have been studied in reference [12]. The description of the studied model cases is described in the following sections.

Stone Column and Soft Soil Model. This analysis aims to get more results about the response of stone columns under seismic loading in soft clayey soil. Two types of model databases (standard/explicit model) were used in this analysis. The first was (2D axisymmetric-deformablesolid) for soft, clay soil, and granular material of stone column according to the problem and loading nature. All elements were quadrilateral quadratic elements. This analysis geometry was divided into two parts that contained stone columns and surrounding soft clay soil. The Mohr-Coulomb model with $(\varphi=0)$ was used to model the undrained behavior of the soft clay soil, and the Drucker-Prager model was used to simulate the elastoplastic behavior of the stone column's granular material. To get more precise (fine mesh) at the areas around and below the stone column base, all of the used elements are (axisymmetric quadrilateral element termed CAX8) with biased node seeding close to the stone column. The soil, stone column, and mesh assembly are shown in Figure 1.

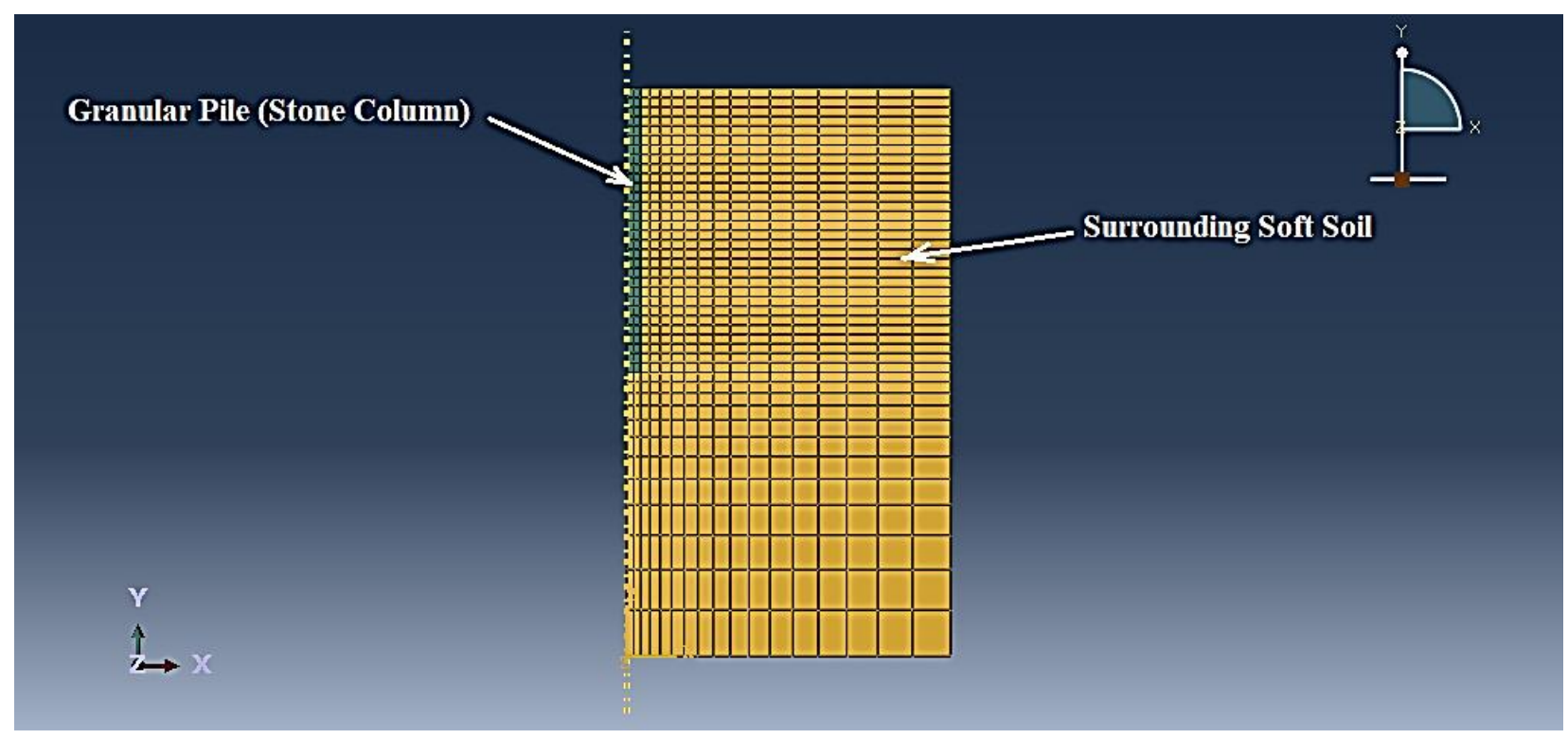

Figure 1. Finite element mesh of the stone column-soft soil system.

The dimensions of the stone column are varied with five (L/D) ratios as $(2,4,6,8$, and 10) with a constant diameter of $(0.03 \mathrm{~m})$, so the length of the stone column ranged as $(0.06,0.12,0.18,0.24$, and $0.3 \mathrm{~m})$. The stone columns that are used in this analysis are embedded in a soft soil profile. The layer is saturated clay soil with a thickness of $(0.6 \mathrm{~m})$ and a width of $(0.7 \mathrm{~m})$. The geotechnical properties of the soft ground and the stone column materials that are used for modeling are presented in Table 2. The designation of studied cases is listed in Table 3. 
Table 2. Properties of natural soft soil and granular material.

\begin{tabular}{|l|c|c|c|c|}
\hline \multirow{2}{*}{ Parameter } & \multirow{2}{*}{ Symbol } & \multirow{2}{*}{ Unit } & Soil (Clay) & Column (Stone) \\
\cline { 4 - 5 } & & & Mohr-Coulomb & Drucker Prager \\
\hline Dry unit weight & $\gamma_{\mathrm{d}}$ & $\mathrm{kN} / \mathrm{m}^{3}$ & 14.68 & 16.81 \\
\hline Saturated unit weight & $\gamma_{\mathrm{sat}}$ & $\mathrm{kN} / \mathrm{m}^{3}$ & 18.93 & 21.68 \\
\hline Young modules & $\mathrm{E}_{\mathrm{ref}}$ & $\mathrm{kN} / \mathrm{m}^{2}$ & 7 & 48 \\
\hline Poissons ratio & $v$ & - & 0.4 & 0.3 \\
\hline Cohesion & $\mathrm{c}_{\text {ref }}$ & $\mathrm{kN} / \mathrm{m}^{2}$ & 15 & 0 \\
\hline Angle of internal friction & $\varphi$ & Degree & 0 & 46 \\
\hline Dilatancy angle & $\psi$ & Degree & 0 & $\psi=\varphi-30=16$ \\
\hline
\end{tabular}

Table 3. Designation of studied cases.

\begin{tabular}{|c|c|c|c|c|}
\hline $\begin{array}{c}\text { Case } \\
\text { No. }\end{array}$ & $\begin{array}{c}\text { Diamter of stone } \\
\text { column, } \mathbf{D}(\mathbf{m})\end{array}$ & $\begin{array}{c}\text { Length of stone } \\
\text { column, } \mathbf{L}(\mathbf{m})\end{array}$ & L/D & Description \\
\hline 0 & 0.03 & 0.00 & 0 & Natural soil \\
\hline 1 & 0.03 & 0.06 & 2 & \multirow{3}{*}{ Soil reinforced with single stone column } \\
\hline 2 & 0.03 & 0.12 & 4 & \\
\hline 3 & 0.03 & 0.18 & 6 & \\
\hline 4 & 0.03 & 0.24 & 8 & \\
\hline 5 & 0.03 & 0.30 & 10 & \\
\hline
\end{tabular}

Steps of Analysis. Three analysis steps were applied in this model according to the nature of the problem. These steps were arranged as initial, geostatic, and seismic steps for experimental seismic study. This study used the surface-to-surface contact discretization technique. As a result, the stone column's soft soil is considered a master surface, while the stone column's surface, which interacts with the soft soil, is considered a slave surface. Substructure projects and insufficiency of the ground in municipal zones are forcing many growing difficulties on the soft clay soils on the embankments. When the area of studying is an active seismic area, advanced engineering trials should be considered the double effects of the seismic hazard constitute a result. The El Centro in the Imperial Valley in southeastern California near the United States earthquake's international border is dependent in this study. This earthquake with a magnitude of 7.1 and peak ground acceleration PGA $=3.50 \mathrm{~m} / \mathrm{s}^{2}$. Body and seismic loading conditions have been applied for a stone column-soil system to get the lateral movement at different parts of a stone column (top and middle of the stone column). Also, lateral acceleration and total strains have been modeled. The 1940 El-Centro earthquake time antiquity is captured in Figure 2.

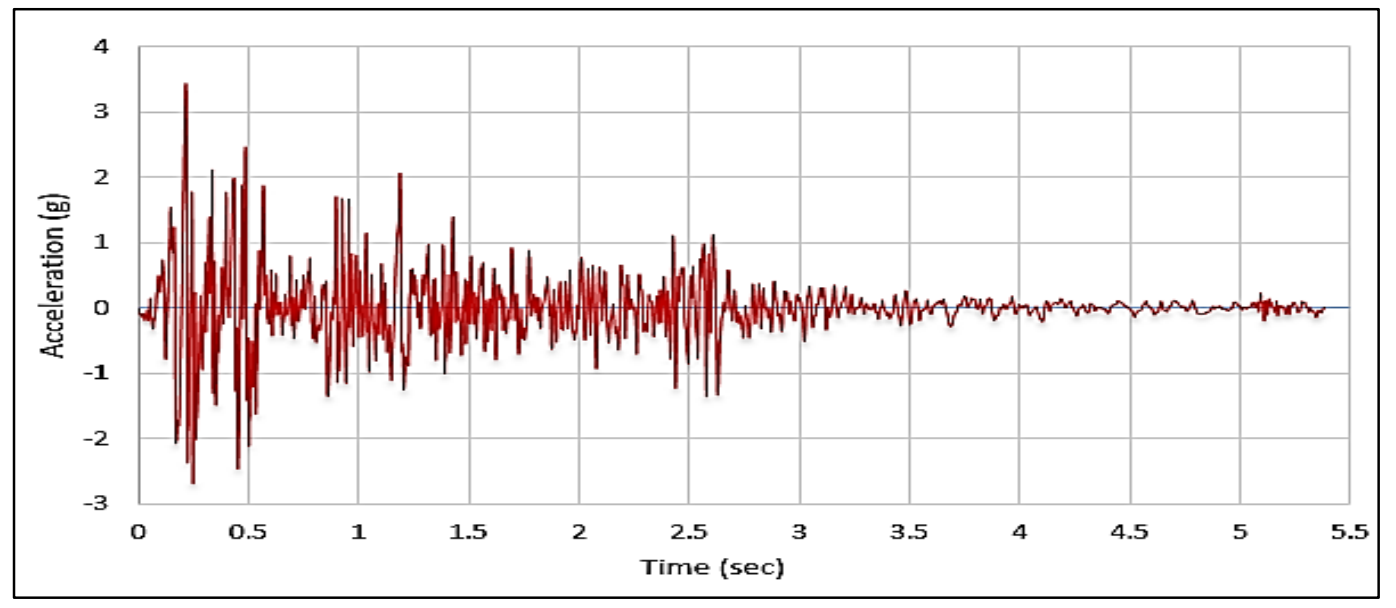

Figure 2. The 1940 El Centro earthquake time antiquity. 


\section{Results and Discussion}

Soft clay soil and granular materials can intensify the low natural cyclic motion during heavy shaking. So, the displacement, velocity, acceleration, and lateral displacement in time histories are examined in this study. A comparing of natural soft soil with five cases of improving the soft soil with a floating stone column of several aspect ratios (L/D) is modeled to get a ground earthquake under the shaking experimental model. Figures 3 to 8 show the response of natural soft clayey soil and soft clay improved by flotation stone columns of several aspect ratios. The response is represented by acceleration, velocity, and displacement measured at the soil surface when subjected to El Centro's earthquake. The improvement of soft soil by floating stone columns reduces the acceleration, velocity, and amplitude of displacement near the top region of a stone column at a short period of the El Centro earthquake.

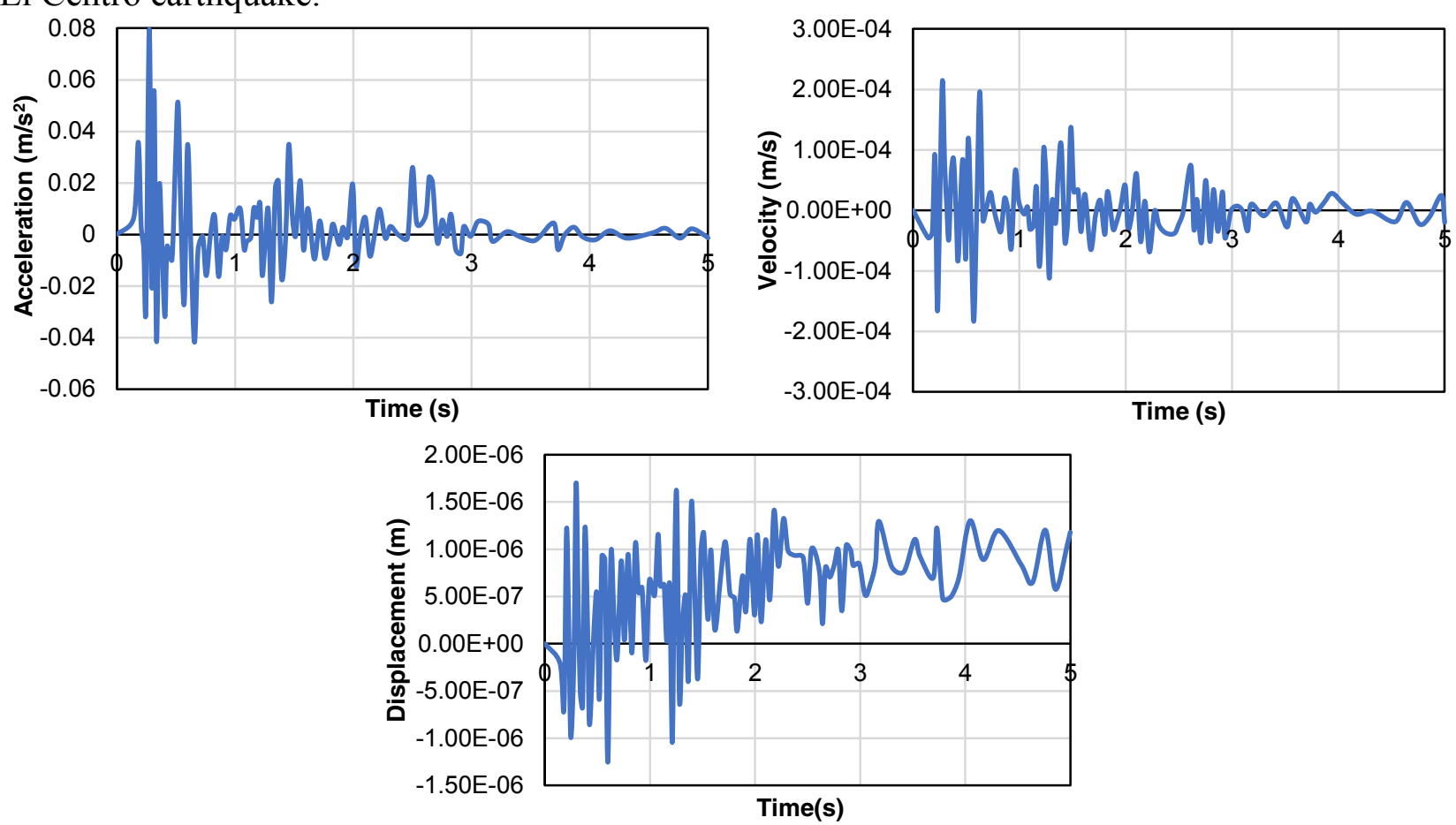

Figure 3. Acceleration, velocity, and displacement responses of natural soil under El Centro earthquake.

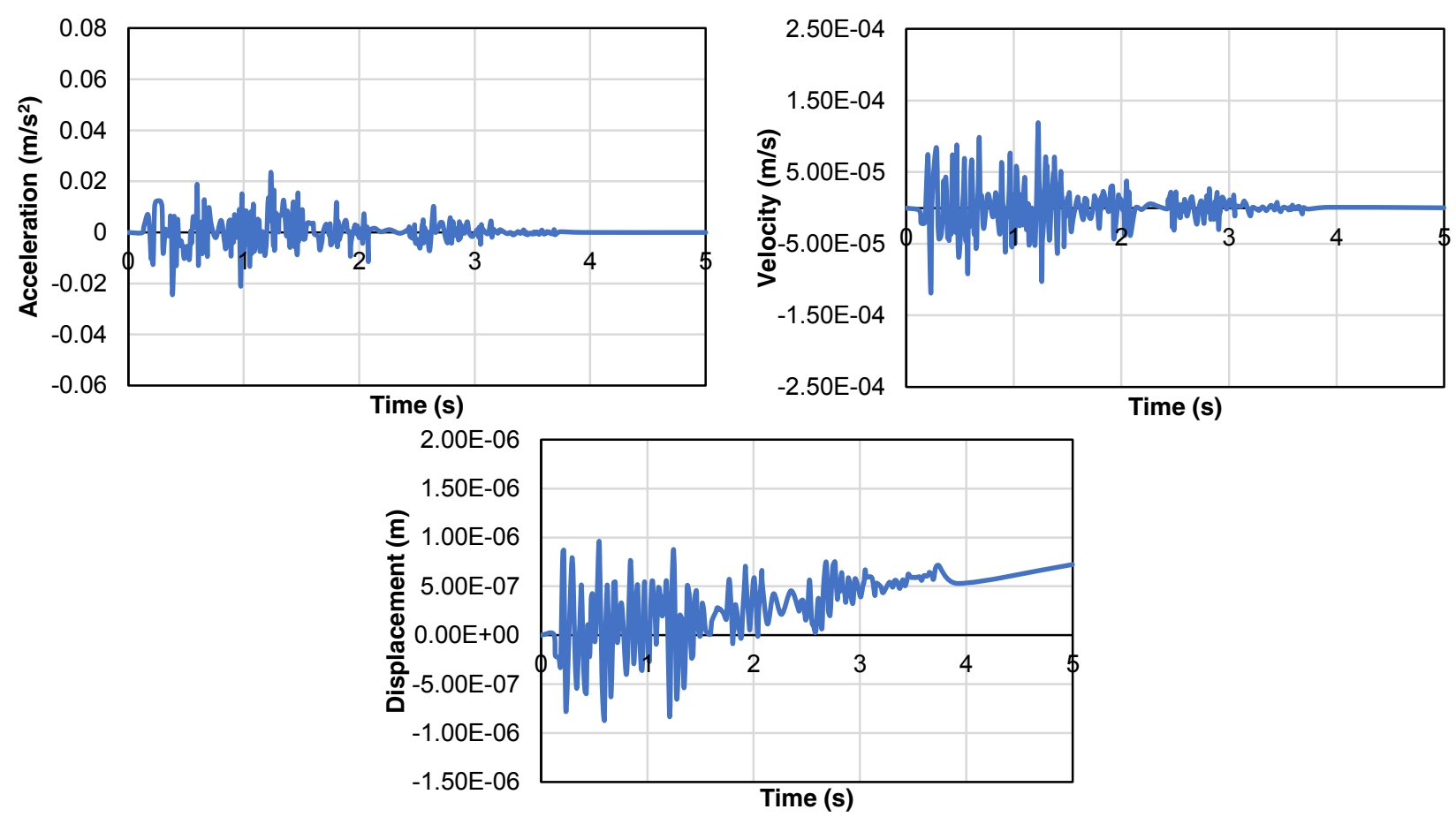

Figure 4. Acceleration, velocity, and displacement responses of case No. 1 under El Centro earthquake. 


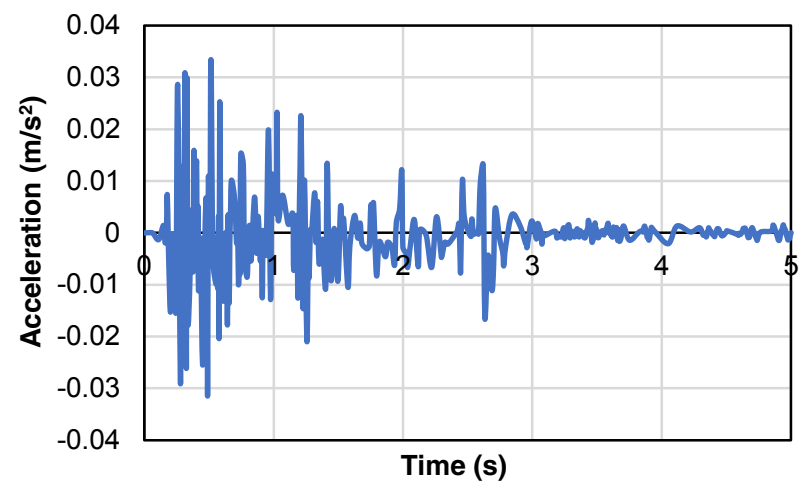

Time (s)
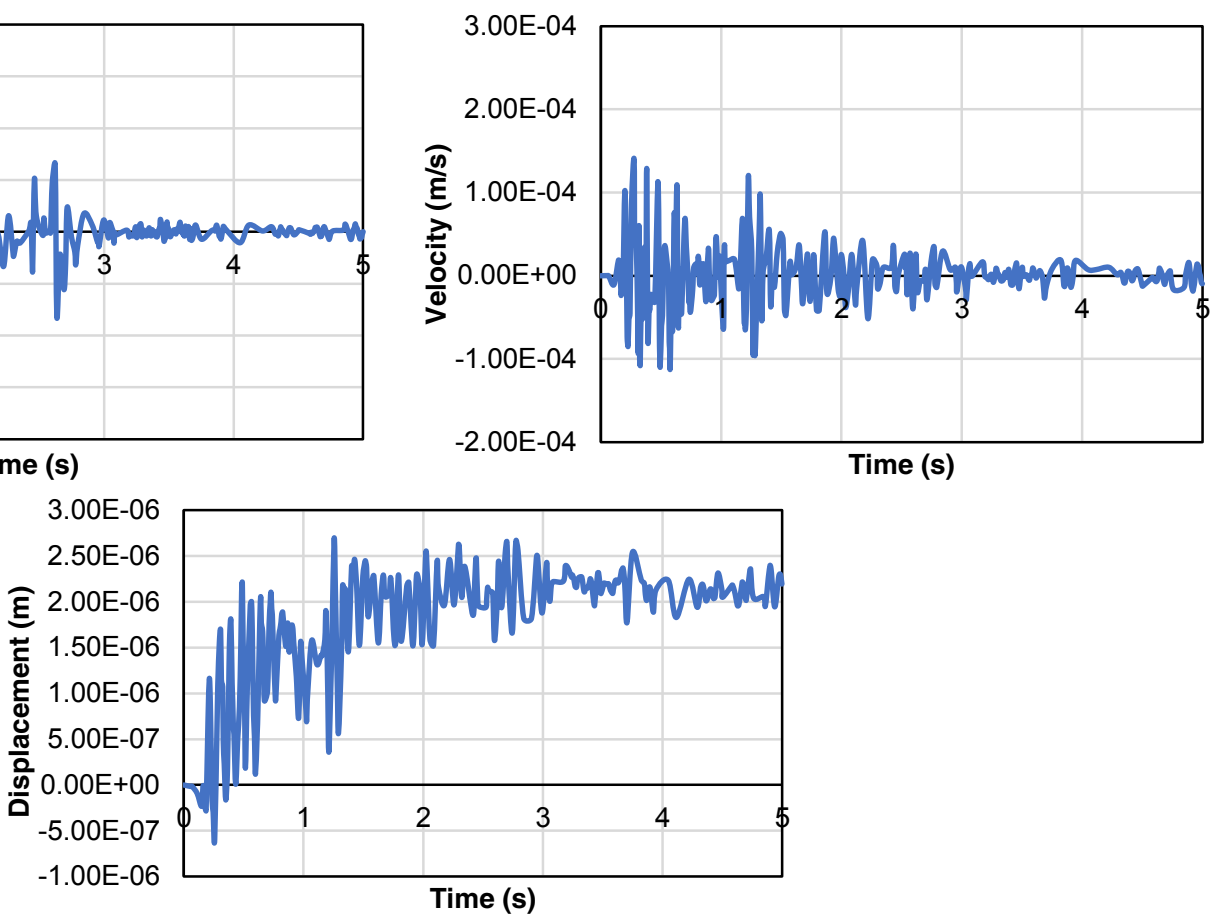

Figure 5. Acceleration, velocity, and displacement responses of case No. 2 under El Centro earthquake.

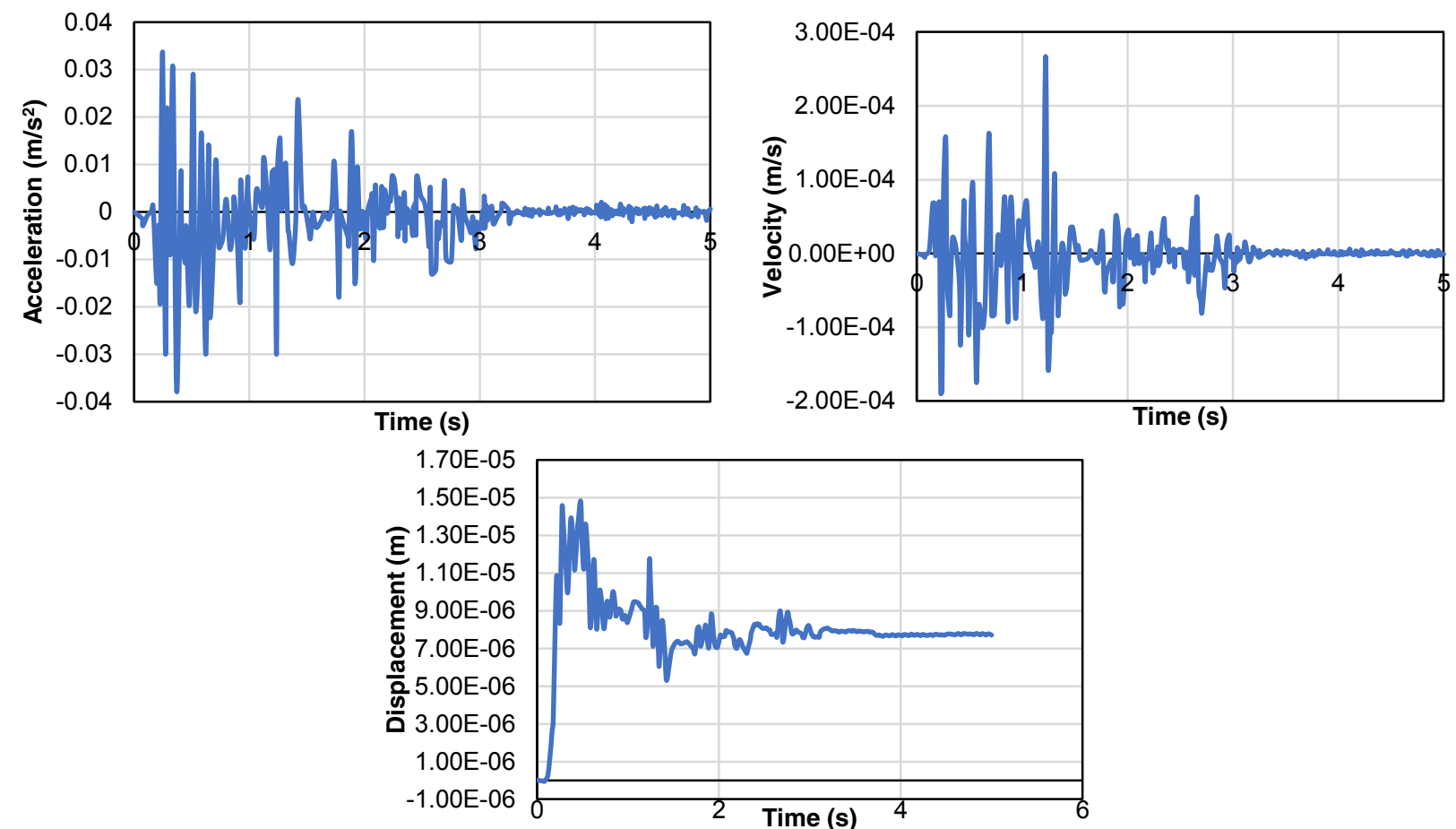

Figure 6. Acceleration, velocity, and displacement responses of case No. 3 under El Centro earthquake.

Decreasing the aspect $(\mathrm{L} / \mathrm{D})$ ratio causes a significant decrease in the generated acceleration at the soil surface, where L/D equals give the lowest acceleration. Also, the same pattern of behavior was noticed for both velocity and displacement at the soil surface. Generally, increasing the diameter of floating stone columns is more significant than the reduction and absorbent length for the earthquake. Increasing the aspect ratio beyond 2 has different effects on the acceleration, velocity, and displacement of soft soil surface improved by floating stone columns. 


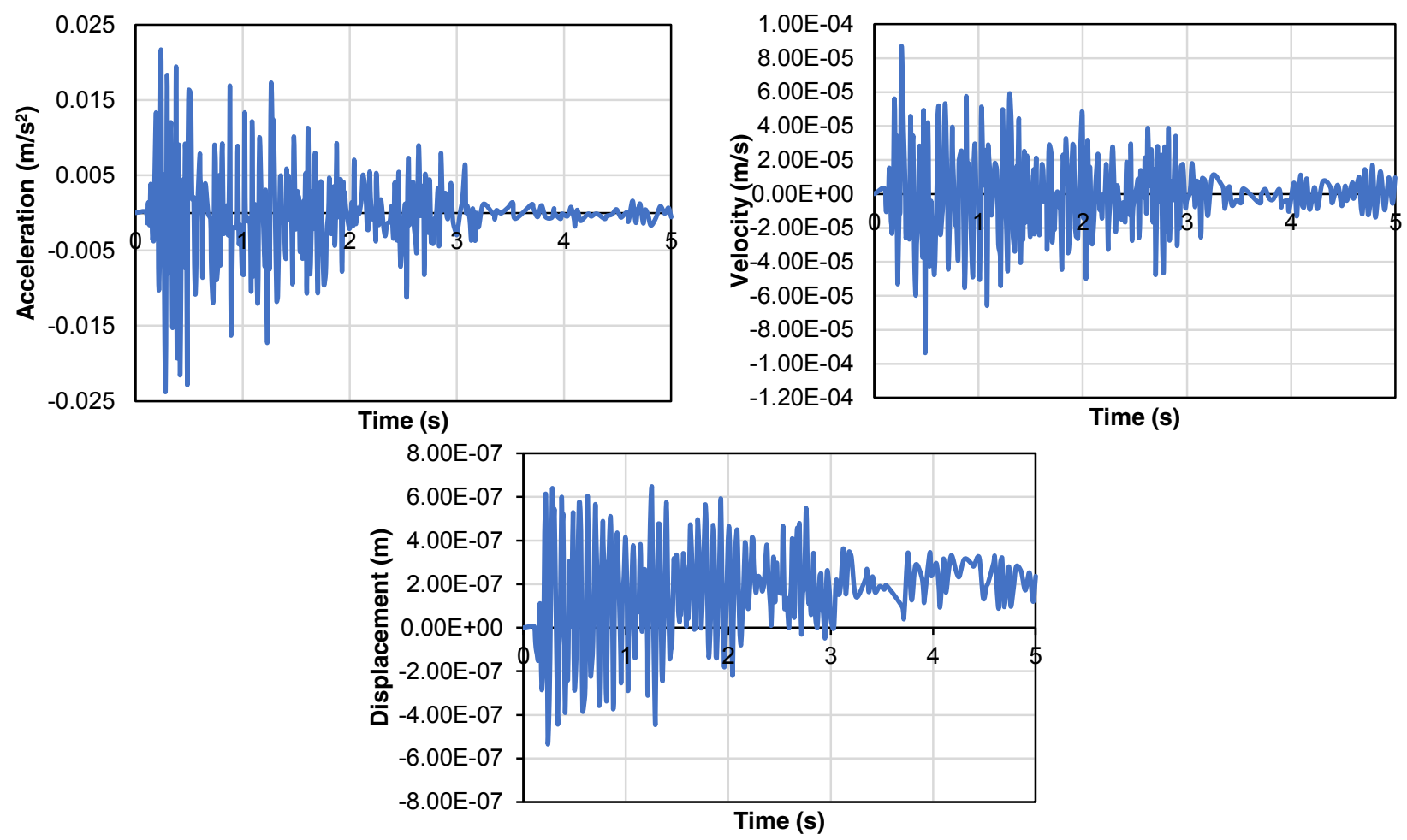

Figure 7. Acceleration, velocity, and displacement responses of case 4 under El Centro earthquake.

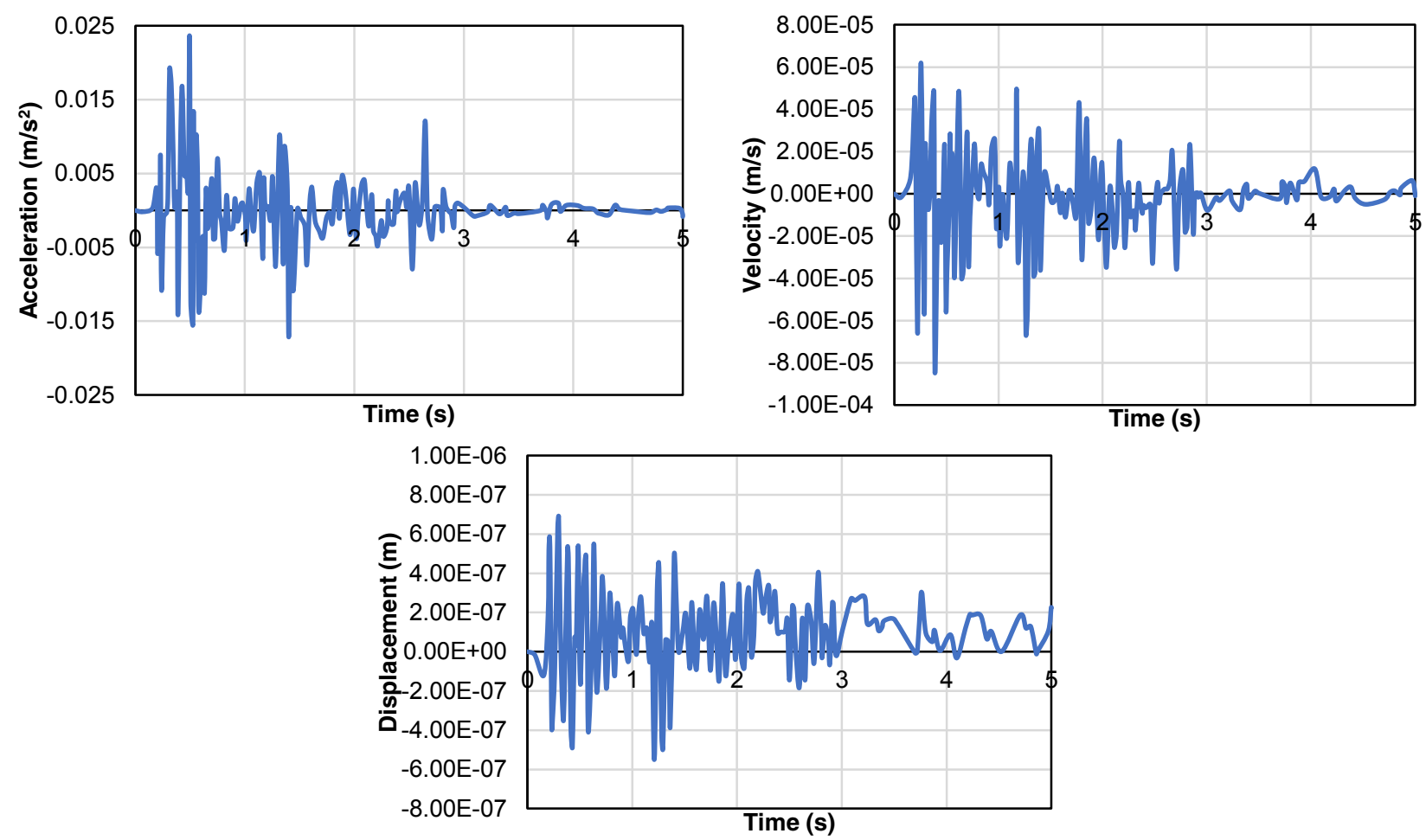

Figure 8. Acceleration, velocity, and displacement responses of case 5 under El Centro earthquake.

Figure 9 displays the lateral displacement response for two points (mid and top regions of the stone column). For the case of soft soil reinforced with a single stone column (short length of stone column), the variation of lateral displacement is the same at the two regions (top and mid) (about $1.5 \mathrm{E}-4 \mathrm{~m}$ ). For other cases, increasing the length of stone columns causes an intensive increase in the lateral displacement of stone columns at the mid-point compared to the top region. 

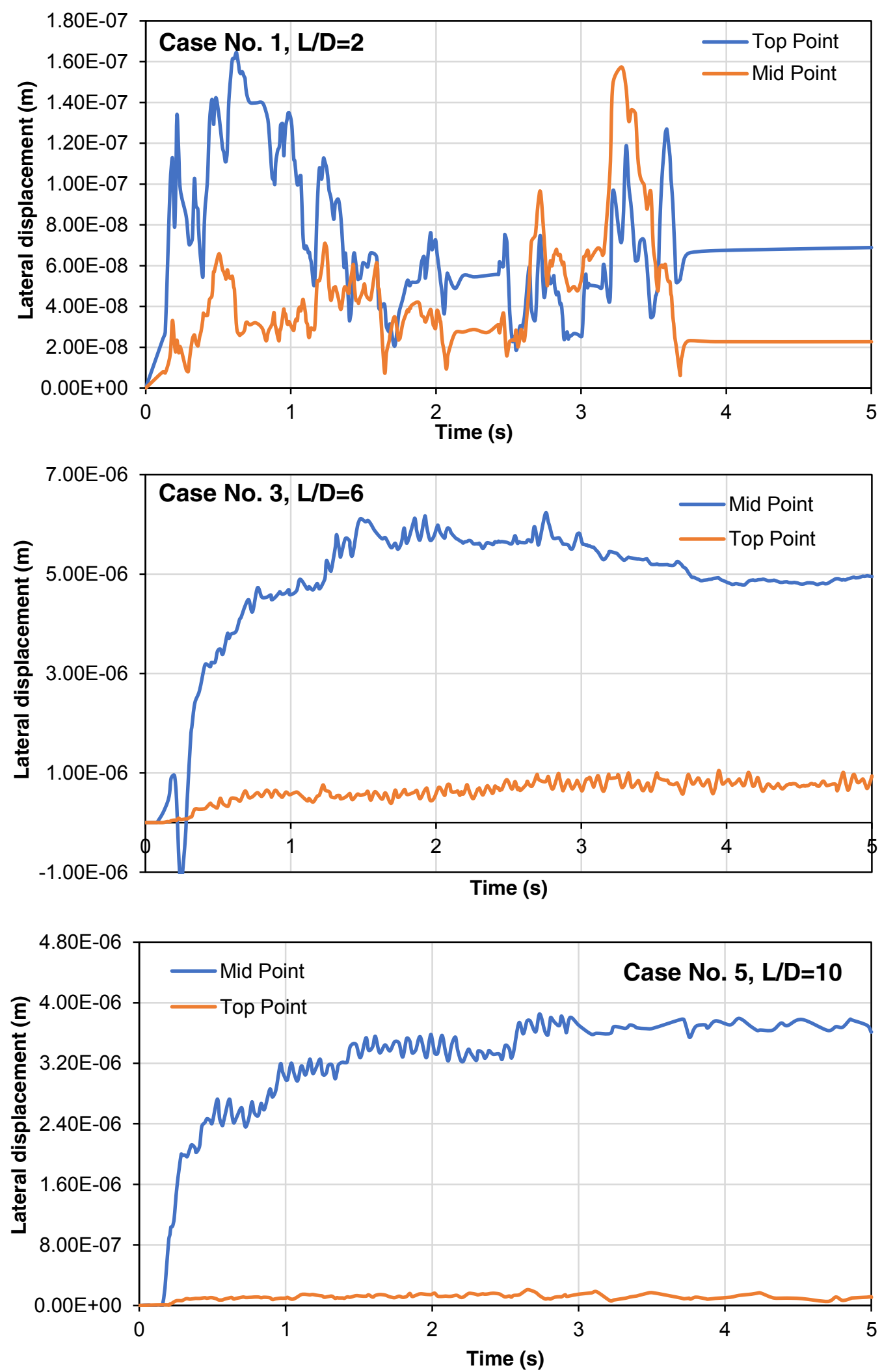

Figure 9. Lateral displacement responses for three cases of stone columns at the top and midpoints.

Figure 10 demonstrates the lateral displacement at the mid-region for the improved soil with a stone column as case 1 and case 5 comparing with the same zone for natural soft soil. The results showed that using stone columns can significantly minimize the lateral variation of the wave prorogation resulted from the earthquake. The deformed lateral displacement under earthquake loading for case $5(\mathrm{~L} / \mathrm{D}=6)$ is shown in Figure 11. 

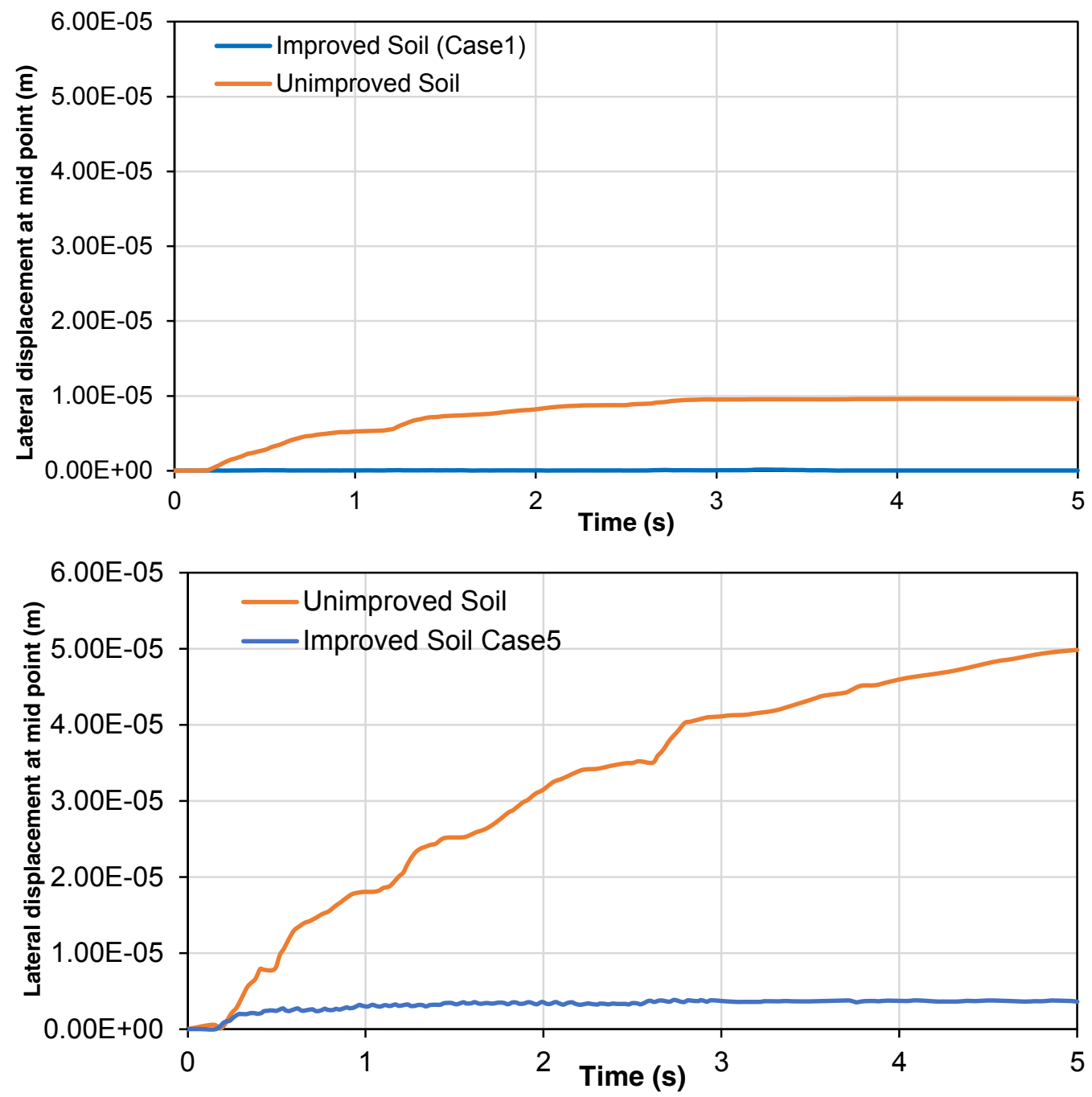

Figure 10. Lateral displacement responses at mid points of improved and natural soil.

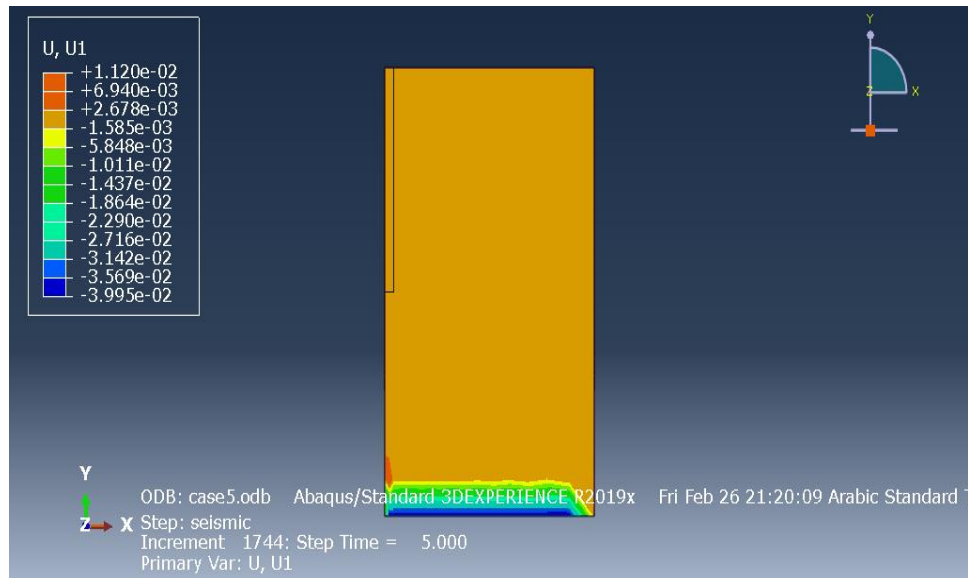

Figure 11. Lateral displacement on a stone column.

\section{Conclusions}

Numerical modeling was used to analyze the seismic performance of the floating stone-columnimproved soft soil. The value of $\mathrm{L} / \mathrm{D}$ ratio and constant diameter determines the seismic response of the floating stone column in soft soil. The surrounding soft clay soil has lower stiffness due to increasing the period of the natural frequency of the soft soil improved with stone columns. Acceleration, displacement, and velocity have been reduced for different cases of floating stone columns in soft clayey soil compared with natural unimproved soft soil. Furthermore, the results 
showed that the same deformation occurs with similar displacements at the top and mid-points of a short stone column. For long stone columns, there is more significant variation between the top and mid regions. This behavior returns to affect the stone column by the horizontally traveling seismic waves.

\section{References}

[1] Abbawi, Z.W.S., 2002. Evaluation of improvment techniques for ballasted railway track model resting on soft clay. Ph.D. Thesis, University of Technology-Iraq.

[2] McKelvey, D., Sivakumar, V., Bell, A. and Graham, J., 2004. Modelling vibrated stone columns in soft clay. Proceedings of the Institution of Civil Engineers-Geotechnical Engineering, 157(3), pp.137-149.

[3] Liu, W. and Hutchinson, T.C., 2018. Numerical investigation of stone columns as a method for improving the performance of rocking foundation systems. Soil Dynamics and Earthquake Engineering, 106, pp.60-69.

[4] Kim, J.M., Lee, H.J. and Ryu, J.H., 2010. Seismic response of stone column-improved soft clay deposit by using $1 \mathrm{~g}$ shaking table. Journal of the Korean Geotechnical Society, 26(12), pp.6170.

[5] Ryu, J.H. and Kim, J.M., 2013. Seismic performance of stone-column-reinforced marine soft soil. EJGE, 18, pp.497-508.

[6] Engelhardt, K. and Golding, H.C., 1975. Field testing to evaluate stone column performance in a seismic area. Geotechnique, 25(1), pp.61-69.

[7] Reddy, C.S. and Mohanty, S., 2017. Seismic behavior of stone column on a sloping layered soil. Sixth Indian Young Geotechnical Engineers Conference.

[8] Zhan, Y., Jiang, G. and Yao, H., 2014. Dynamic characteristics of saturated silty soil ground treated by stone column composite foundation. Advances in Materials Science and Engineering, 2014.

[9] Qu, M., Xie, Q., Cao, X., Zhao, W., He, J. and Jin, J., 2016. Model test of stone columns as liquefaction countermeasure in sandy soils. Frontiers of Structural and Civil Engineering, 10(4), pp.481-487.

[10] Maharaj, D.K., 2003. Load-settlement behavior of piled raft foundation by three-dimensional nonlinear finite element analysis. Electronic Journal of Geotechnical Engineering, 8, pp.12571263.

[11] Manual, A.S.U.S., 2012. Abaqus 6.11. http://130.149, 89(2080), p.v6.

[12] Karkush, M. and Jabbar, A., 2019. Improvement of soft soil using linear distributed floating stone columns under foundation subjected to static and cyclic loading. Civil Engineering Journal, 5(3), pp.702-711.

[13] Balaam, N.P. and Booker, J.R., 1981. Analysis of rigid rafts supported by granular piles. International journal for numerical and analytical methods in geomechanics, 5(4), pp.379403.

[14] Son, S.W., Bagheri, P. and Kim, J.M., 2019. Dynamic Behavior of Ground Improved Using a Crushed Stone Foundation Wall. Sustainability, 11(10), p.2767.

[15] Wriggers, P., 1995. Finite element algorithms for contact problems. Archives of computational methods in engineering, 2(4), pp.1-49. 